\title{
Identifikasi Hambatan pada Penanganan Penanggulangan Kebakaran di Wilayah Jakarta Timur Menggunakan Metode Bowtie Analysis dan A'WOT Analysis
}

\author{
Fajar Septian $^{(1, a) *}$, Tatan Sukwika ${ }^{(1)}$ dan Maya Dewi Dyah Maharani ${ }^{(1)}$ \\ (1) Program Studi Magister Manajemen, Keselamatan Kesehatan Kerja Dan Lingkungan, \\ Universitas Sahid, Jakarta, Indonesia \\ Email : ${ }^{\left({ }^{*}\right)}$ fajarseptian38@gmail.com
}

Diterima (25 November 2021), Direvisi (30 Desember 2021)

\begin{abstract}
Increased population density, community activities, lack of infrastructure and people unable to cope with fires are fire-prone areas. This study aims to identify barriers to fire prevention in the East Jakarta area so that fires can be prevented and dealt with properly. This study uses a qualitative descriptive analysis method with content analysis, bowtie analysis and $A^{\prime}$ WOT analysis. The results show that the response time of the officers according to the target time reached $98 \%$ and $2 \%$ did not, the most fire objects were residential buildings $28 \%, 81 \%$ extinguished by officers and $19 \%$ extinguished by the community, the area that covers a radius of $2 \mathrm{~km}$ from the $160.59 \mathrm{Km} 2$ fire post service has not been reached $27,44 \mathrm{Km} 2$. Bowtie's analysis shows the hazard of fire, the top event is limited in fire management supervision, the threat response time is more than 15 minutes the barrier increases the preparedness and skills of officers, uses an effective, fast, and accurate fire report application, the threat of lack of coverage area of the barrier post increases the number of fire stations. fires, providing fire extinguishers and hydrants. The A'WOT analysis shows the quadrant IV integration strategy, conditions that grow and develop. It can be concluded that the lack of service coverage areas and fire facilities and infrastructure in the community can inhibit fire fighting. The managerial implication is expected to increase the number of posts to support the punctuality of the response time of officers, facilitate socialization, training, fire simulations on a regular basis and thoroughly to the public so that they are more concerned about the threat of fire hazards.
\end{abstract}

Keywords: Officer response time, fire department service coverage area, fire prevention and control

\begin{abstract}
Abstrak. Peningkatan kepadatan penduduk, aktifitas masyarakat, kurangnya infrastruktur dan masyarakat tidak mampu mengatasi kebakaran merupakan daerah rentan kebakaran. Penelitian ini bertujuan mengidentifikasi hambatan petugas dalam penanggulangan kebakaran di wilayah Jakarta timur agar kebakaran dapat dicegah dan dihadapi dengan baik. Penelitian menggunakan metode analisis deskriptif kualitatif dengan alat analisis content analysis, bowtie analysis dan analisis A'WOT. Hasil menunjukan respon time petugas sesuai target waktu mencapai $98 \%$ dan $2 \%$ tidak, obyek kebakaran terbanyak bangunan perumahan $28 \%$, pemadaman oleh petugas $81 \%$ dan dipadamkan masyarakat $19 \%$, luas area yang menjangkau radius $2 \mathrm{~km}$ pelayanan pos pemadam $160,59 \mathrm{Km}^{2}$ belum terjangkau $27,44 \mathrm{Km}^{2}$. Bowtie analisis menunjukan hazard terjadinya kebakaran, top event keterbatasan pengawasan manajemen kebakaran, threat respon time lebih dari 15 menit barriernya meningkatkan kesiapsiagaan serta keterampilan petugas, menggunakan aplikasi laporan kebakaran yang efektif, cepat, dan tepat, threat kurangnya area jangkauan pos barriernya meningkatkan jumlah pos pemadam kebakaran, menyediakan APAR dan hidran. Analisis A'WOT menunjukan strategi integrasi kuadran IV, kondisi yang tumbuh dan berkembang. Dapat disimpulkan kurangnya area jangkauan pelayanan serta sarana dan prasarana kebakaran dimasyarakat dapat menghambat pemadaman kebakaran. Implikasi manajerialnya diharapkan untuk meningkatkan jumlah pos dalam mendukung ketepatan waktu respon time petugas, mempermudah sosialisasi, pelatihan, simulasi kebakaran secara berkala dan menyeluruh kepada masyarakat agar lebih peduli terhadap ancaman bahaya kebakaran.
\end{abstract}

Kata Kunci: Respon time petugas, area jangkauan pelayanan pos pemadam kebakaran, pencegahan dan penanggulangan kebakaran. 


\section{PENDAHULUAN}

Bencana kebakaran dapat terjadi karena perilaku tidak aman masyarakat di lingkungan tempat tinggalnya dengan menyimpan, membawa serta meletakan barang atau bahan mudah terbakar langsung terhubung atau dekat dengan sumber penyalaan. Pemahaman masyarakat yang masih kurang terkait potensi bahaya bencana kebakaran yang dapat mengancam serta tidak mengetahui cara pencegahan dan pemadaman kebakaran dini sebelum api kebakaran membesar agar terhindar dari kerugian akibat bencana kebakaran. Hal ini tentu saja dapat mengakibatkan sistem pencegahan bencana kebakaran tidak menjadi prioritas utama di lingkungan perumahan masyarakat.

Beberapa faktor penghambat penanggulangan kebakaran serta peningkatan terjadinya kebakaran seperti meningkatnya jumlah masyarakat pendatang yang tinggal di Jakarta serta lonjakan pertumbuhan penduduk yang terjadi di ibukota menyebabkan permintaan untuk pemukiman yang aman serta nyaman semakin tinggi. Sedangkan sarana dan prasarana pencegahan kebakaran yang ada belum tersedia dengan baik sehingga keselamatan masyarakat di lingkungan perumahan akan terancam oleh peristiwa kebakaran apabila terjadi di permukiman masyarakat. Peningkatan kepadatan penduduk, aktifitas kehidupan masyarakat, infrastruktur yang minim di daerah padat penduduk dan masyarakat yang tidak mampu mengatasi ancaman kebakaran merupakan daerah yang rentan terhadap kebakaran [1].

Sudin Penanggulangan Kebakaran merupakan wakil pemda Jakarta dalam mengatasi permasalahan penanggulangan kebakaran dengan landasan perundangan sebagai dasar kebijakan pemerintah yang memiliki sumber daya, pengembangan sumber daya, lembaga penelitian serta menjangkau setiap masyarakat yang membutuhkan pertolongan terkait bencana kebakaran dan penyelamatan kapan pun di DKI Jakarta khususnya wilayah Jakarta Timur. Mengidentifikasi hambatan yang dihadapi oleh petugas pemadam kebakaran baik dalam pencegahan maupun saat penanggulangan kebakaran kemudian mencari solusi terbaik untuk mengatasi hambatan tersebut sangat penting, agar masyarakat, instansi terkait dan petugas pemadam kebakaran mampu bekerjasama dalam mencegah serta menghadapi dengan baik bahaya kebakaran yang selalu mengancam setiap saat. Penelitian dilaksanakan dengan tujuan mengetahui trend kejadian kebakaran pada wilayah Jakarta Timur untuk tahun 2020, mengetahui hambatan petugas saat penanganan penanggulangan bencana kebakaran dan mengetahui strategi yang dilakukan.

\section{METODE PENELITIAN}

Desain Penelitian menggunakan model penelitian Deskriptif kualitatif. Data dikumpulkan dengan melaksanakan observasi dan wawancara secara langsung melalui informan yang bertujuan mendapatkan informasi terkait fakta kejadian serta kondisi sesuai pada keadaan sebenarnya. Indikator atau variabel penelitian yang digunakan merupakan salah satu realisasi indikator kinerja dinas penanggulangan kebakaran serta penyelamatan DKI Jakarta yang terdapat pada rencana strategis 2017 - 2022 yaitu tingkat keberhasilan atau ketercapaian waktu tanggap petugas pemadam kebakaran terhadap kejadian kebakaran dengan target waktu respon time lima belas menit, tingkat keberhasilan rata - rata waktu pemadaman oleh petugas sebesar seratus dua puluh menit, tingkat keberhasilan kebakaran dini yang dapat diatasi atau dipadamkan oleh warga serta tingkat ketercapaian radius area 
pelayanan pos pemadam kebakaran dua setengah kilo meter terhadap pemukiman masyarakat yang ada di wilayahnya [2].

Penganalisaan data dilaksanakan dengan beberapa tahapan antara lain melaksanakan analisa data skunder yaitu data yang didapatkan dari laporan kejadian kebakaran selama tahun 2020 kemudian melakukan pengolahan data skunder yang di klasifikasikan menurut wilayah kecamatan yang ada di Jakarta Timur. Serta melakukan wawancara secara mendalam dengan petugas pemadam kebakaran wilayah Jakarta Timur dengan panduan wawancara dari hasil pengolahan data skunder. Kemudian dari data skunder dan data primer hasil wawancara akan dianalisis menggunakan analisis content untuk mengidentifikasi hambatan yang terjadi. Menganalisis makna konten dalam teks untuk pelabelan dokumen secara sistematis. content analysis dipakai dalam metode penelitian agar diketahui kecendrungan isi komunikasi [3]. Tahap selanjutnya melaksanakan analisis Risiko penanganan penanggulangan kebakaran yang terjadi dengan menggunakan Bowtie analisis. Teknik analisis risiko Bowtie memiliki berbagi keunggulan yaitu di pakai untuk menentukan potensi bahaya serta melakukan pelatihan untuk mengendalikan potensi tersebut. Bowtie analisis dipakai dalam penyusunan kajian risiko yaitu Hazards Effects Managemen Plan (HEMP). Diagram Bowtie analisis menunjukan gabungan dari Fault Tree Analysis bagian kiri dan Event Tree Analysis bagian kanan yang memungkinkan dalam menganalisis potensi bahaya yang terjadi pada sisi sebab akibat secara menyeluruh [4].

Kemudian dari pengembangan hasil wawancara dapat dibuat kuesioner untuk menentukan strategi dalam pelaksanaan tugas pencegahan dan penanggulangan kebakaran di wilayah Jakarta Timur peneliti menggunakan pendekatan analisis A'WOT. Analisis strategi A'WOT terdiri dari dua analisis strategi yaitu Analytic Hierarchy Process (AHP) yang digunakan untuk mendefinisikan permasalahan yang ada dengan menentukan tujuan yang akan dicapai kemudian mengidentifikasi beberapa kriteria yang dibutuhkan dalam pencapaian tujuan dan pembuatan struktur hierarki dari pemecahan permasalahan kemudian melaksanakan penghitungan Nilai Total Eigen Vektor Normalisasi perbandingan berpasangan komponen SWOT internal dan eksternal faktor menggunakan analisis AHP yang menghasilkan nilai bobot untuk menentukan nilai Internal Factor Analysis Summary (IFAS) dan Eksternal Factor Analysis Summary (EFAS). Penggunaan analisis strategi AHP adalah untuk menjabarkan permasalahan yang ada agar lebih sederhana dan mudah untuk mencari solusinya dalam mencapai tujuan yang di inginkan dengan menentukan skala prioritas yang di susun dari beberapa tingkatan komponen [5].

Serta analisis strategi SWOT yang digunakan untuk menganalisis dan mengukur kekuatan organisasi, kelemahan organisasi, peluang organisasi dan ancaman organisasi dengan penghitungan nilai matriks Internal Factors Analysis Summary (IFAS) serta Eksternal Factors Analysis Summary (IFAS), kemudian penghitungan nilai Eksternal Factor Evaluation ( EFE ) dan Internal Factor Evaluation ( IFE ) untuk dapat menentukan arah strategi dalam pengembangan organisasi dimasa depan kemudian menentukan matriks TOWS atau SWOT yang menggambarkan strategi alternatif organisasi [6]. 


\section{HASIL DAN PEMBAHASAN}

\section{Trend Kejadian Kasus Kebakaran Tahun 2020 pada Wilayah Kecamatan di Jakarta Timur}

Kejadian kebakaran yang terbanyak terjadi di kecamatan duren sawit 60 kejadian atau $17 \%$, cakung 56 kejadian atau $16 \%$, pulo gadung 48 kejadian atau $14 \%$, cipayung 40 kejadian atau $11 \%$, jatinegara 36 kejadian atau $10 \%$, ciracas 28 kejadian atau $8 \%$, kramat jati 27 kejadian atau $8 \%$, pasar rebo 21 kejadian atau $6 \%$, matraman 17 kejadian atau 5\%, makasar 14 kejadian atau $4 \%$. Kejadian kebakaran berdasarkan penyebab awal kebakaran yang terbanyak disebabkan oleh listrik 218 kejadian atau 63 $\%$ seperti arus pendek listrik akibat instalasi listrik yang tidak sesuai standar serta penambahan colokan listrik yang menumpuk tanpa memperhatikan keamanannya.

Untuk mencegah terjadinya kebakaran masyarakat diharapkan memperhatikan keamanan dalam beraktifitas serta memahami potensi penyebab kebakaran yang ada di lingkungannya, selalu waspada serta mampu menghadapi dengan baik jika terjadi kebakaran dengan memadamkan api awal kebakaran yang terjadi agar tidak membesar menggunakan peralatan yang ada seperti handuk, karung ghoni atau kain yang telah dibasahi air atau dengan menggunakan alat pemadam APAR. Dari hasil wawancara serta data kejadian kebakaran menunjukan trend kejadian kebakaran yang tertinggi terjadi di kecamatan duren sawit, cakung dan pulo gadung karena wilayah kecamatan tersebut merupakan daerah yang padat penduduk serta banyak bangunan industri yang rentan tejadi kebakaran disebabkan masih kurangnya peralatan, sarana dan prasarana penanggulangan kebakaran, proteksi kebakaran aktif dan pasif pada bangunan masih terbatas serta wilayah tersebut jauh dari sumber air dengan akses jalan yang terbatas. Kemudian dari pemetaan wilayah rentan terhadap area jangkauan pelayanan pos pemadam kebakaran di wilayah tersebut masih terdapat daerah yang belum terjangkau.

\section{Kejadian Kebakaran Berdasarkan Obyek Kebakaran}

Dari hasil pengolahan data laporan kebakaran yang terjadi di wilayah Jakarta Timur pada tahun 2020 berdasarkan obyek kebakaran yang terbanyak terjadi pada bangunan perumahan 98 kejadian atau 28 $\%$, kemudian obyek kebakaran pada instalasi luar gedung 91 kejadian atau $26 \%$, kemudian obyek kebakaran pada obyek lain - lain seperti lapak pedagang, tanaman atau pohon, alang-alang, sampah dan lainnya 59 kejadian atau $17 \%$, kemudian obyek kebakaran pada bangunan umum 57 kejadian atau $16 \%$, kemudian obyek kebakaran kendaraan 35 kejadian atau 10 $\%$, kemudian obyek kebakaran bangunan industri 9 kejadian atau $3 \%$. Bangunan perumahan merupakan bangunan yang paling rentan terjadi kebakaran karena beberapa faktor yaitu kurangnya perawatan dan perbaikan instalasi listrik pada bangunan perumahan serta batas usia komponen dari peralatan listrik telah melebihi umur pemakaian, penggunaan colokan listrik yang menumpuk dapat menyebabkan kelebihan beban serta menimbulkan panas pada kabel, peralatan elektronik atau listrik yang dapat terbakar, tidak adanya proteksi kebakaran aktif maupun proteksi kebakaran pasif yang ada pada bangunan perumahan sehingga apabila terjadi kebakaran tidak dapat dicegah dan dikendalikan serta perilaku tidak aman masyarakat sangat berpotensi terjadinya kebakaran di lingkungan pemukiman masyarakat. 


\section{Respon Time Petugas terhadap laporan peristiwa Kebakaran}

Dari hasil pengolahan data laporan kebakaran yang terjadi di wilayah Jakarta Timur pada tahun 2020. Berdasarkan respon time petugas terhadap peristiwa kebakaran yang terjadi di Jakarta Timur tahun 2020 jumlah terbanyak dengan waktu tanggap $0-5$ menit 149 kejadian atau 43 $\%$, kemudian dengan waktu tanggap $6-10$ menit 125 kejadian atau $36 \%$, kemudian waktu tanggap 11 - 15 menit 68 kejadian atau $19 \%$, untuk standar waktu tanggap petugas terhadap kejadian kebakaran di Indonesia adalah 15 menit maka tingkat keterlambatan dengan waktu $16-30$ menit mencapai 7 kejadian atau $2 \%$ sedangkan tingkat keberhasilannya mencapai 342 kejadian atau $98 \%$. Tingkat keterlambatan ini dapat disebabkan situasi lalulintas yang padat sehingga menghambat petugas untuk menuju lokasi kebakaran, masyarakat yang tidak tertib berlalulintas dengan memarkirkan kendaraannya di pinggir jalan dan tidak memberikan jalan atau mengutamakan akses jalan untuk kendaraan operasional petugas, terdapat beberapa wilayah tidak terjangkau oleh area jangkauan pelayanan pos pemadam Kebakaran di wilayah Jakarta Timur serta akses jalan yang sempit juga menyulitkan kendaraan operasional pemadam kebakaran untuk datang ke lokasi kebakaran.

\section{Kejadian Kebakaran Berdasarkan Kesiapsiagaan Petugas dan Masyarakat}

Dari hasil pengolahan data laporan kebakaran yang terjadi di wilayah Jakarta Timur pada tahun 2020 berdasarkan kesiapsiagaan petugas dan masyarakat dalam usaha pemadaman kebakaran yang terjadi di Jakarta Timur tahun 2020. Kejadian kebakaran yang dapat dipadamkan atau diantisipasi oleh masyarakat sebesar 66 kejadian atau $19 \%$, sedangkan kejadian kebakaran yang dapat dipadamkan petugas pemadam kebakaran sebesar 283 kejadian atau $81 \%$. Partisipasi keterlibatan masyarakat sangat diharapkan untuk mencegah terjadinya kebakaran serta untuk pengendalian dalam menghadapi kejadian kebakaran, agar masyarakat tidak rentan terhadap kejadian kebakaran dan dapat mengatasi dengan baik menggunakan sumber daya yang ada di masyarakat apabila terjadi kebakaran dilingkunganya. Untuk itu, petugas pemadam kebakaran selalu melakukan sosialisasi ditengah masyarakat terkait faktor penyebab kebakaran, pencegahan serta bagaimana cara menghadapi dengan baik apabila terjadi kebakaraan di lingkungan masyarakat dengan melakukan simulasi kebakaran dan pemadaman api awal kebakaran menggunakan karung ghoni atau kain atau handuk yang telah dibasahi dan cara pemadaman kebakaran menggunakan apar untuk meningkatkan kesadaran, kewaspadaan serta kesiapsiagaan masyarakat.

\section{Area jangkauan pelayanan pos pemadam Kebakaran di wilayah Jakarta Timur}

Berdasarkan rencana strategis realisasi kinerja pelayanaan Dinas Gulkarmat DKI Jakarta 2017 - 2022 rata - rata radius area jangkauan pelayanan pos pemadam kebakaran di wilayah DKI Jakarta khususnya wilayah Jakarta Timur telah mencapai radius dua kilometer sampai dengan satu setengah kilometer. Tampilan peta radius area pelayanan pos pemadam kebakaran yang berada di wilayah Jakarta Timur menunjukan dari luas wilayah Jakarta Timur 188,03 $\mathrm{Km}^{2}$ luas area jangkauan pelayanan pos pemadam kebakaran yang menjangkau masyarakat sebesar $160,59 \mathrm{Km}^{2}$ atau $85 \%$ sedangkan luas area yang belum terjangkau dengan radius jangkauan pelayanan pos pemadam kebakaran sebesar 27,44 $\mathrm{Km}^{2}$ atau $15 \%$. 


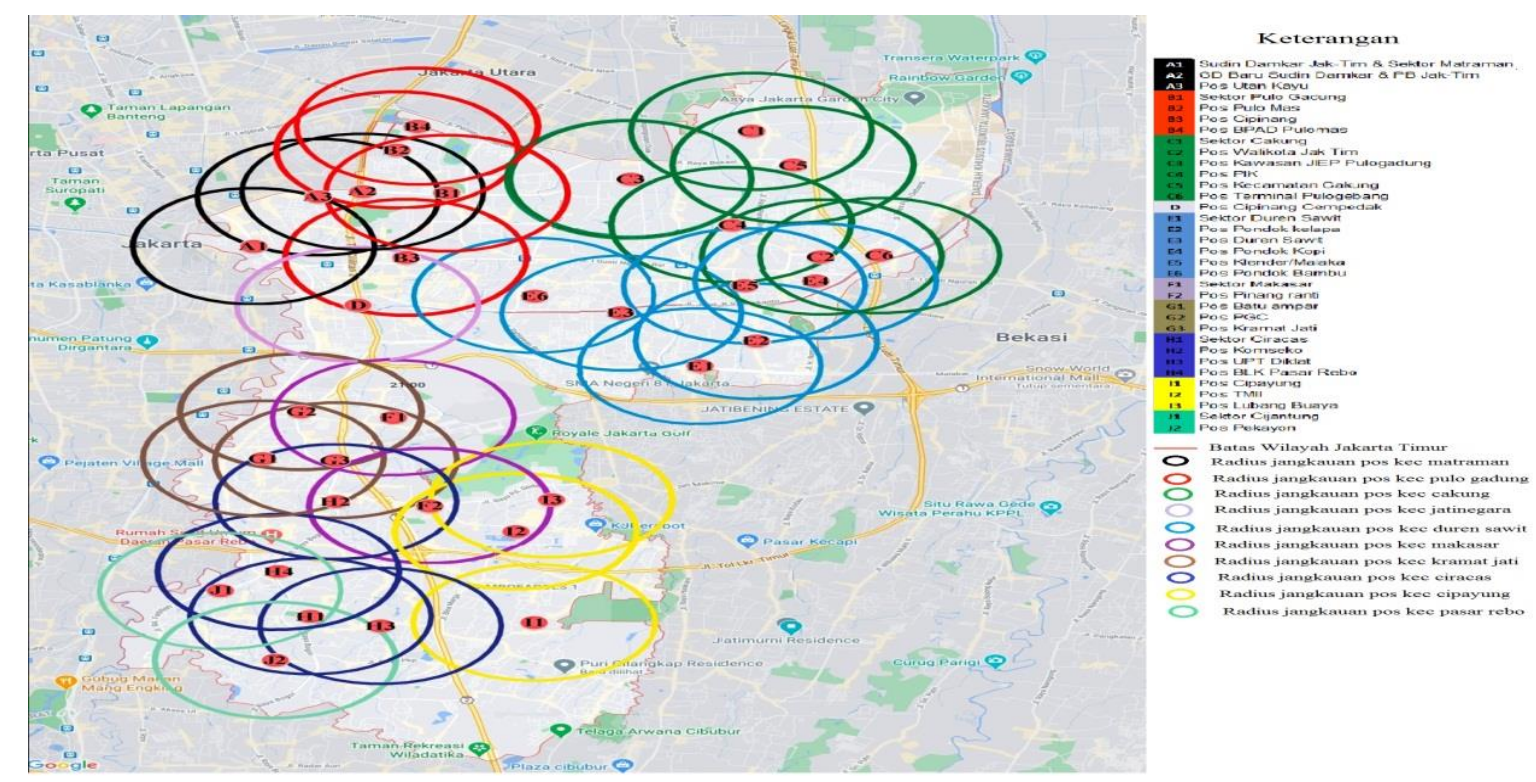

Gambar 1. Titik lokasi dan radius area jangkauan layanan pos pemadam kebakaran

Tabel 1. Area pelayanan pos pemadam kebakaran yang belum terjangkau.

\begin{tabular}{|c|c|c|}
\hline Kelurahan & Kecamatan & $\begin{array}{c}\text { Luas area } \\
\text { yang } \\
\text { belum } \\
\text { terjangkau } \\
\left(\mathrm{Km}^{2}\right) \\
\end{array}$ \\
\hline $\begin{array}{l}\text { Cakung Barat } \\
\text { dan Jatinegara }\end{array}$ & Cakung & 0,87 \\
\hline $\begin{array}{lr}\text { Cakung } & \text { Timur, } \\
\text { Ujung } & \text { Menteng } \\
\text { dan pulo Gebang }\end{array}$ & Cakung & 8,09 \\
\hline $\begin{array}{l}\text { Halim, Cipinang } \\
\text { melayu }\end{array}$ & Makasar & 4,55 \\
\hline Setu, Cilangkap & Cipayung & 1,68 \\
\hline $\begin{array}{l}\text { Pondok Ranggon, } \\
\text { Munjul, Cibubur, } \\
\text { Kelapa Dua } \\
\text { Wetan }\end{array}$ & $\begin{array}{l}\text { Ciracas dan } \\
\text { Cipayung }\end{array}$ & 11,50 \\
\hline Kali Sari & Pasar rebo & 0,61 \\
\hline $\begin{array}{l}\text { Bale Kambang, } \\
\text { Cawang }\end{array}$ & Kramat Jati & 0,14 \\
\hline \multicolumn{2}{|l|}{ Total } & 27,44 \\
\hline
\end{tabular}

Penyebaran lokasi pos pemadam kebakaran belum merata ke seluruh wilayah yang ada di Jakarta Timur untuk itu perlu penambahan pos pada lokasi area pelayanan yang belum menjangkau masyarakat.

\section{Bowtie Analisis}

Untuk mengidentifikasi hambatan pada penanganan penanggulangan kebakaran di wilayah Jakarta Timur penulis menggunakan diagram bowtie analisis dengan menentukan hazard atau bahaya yaitu potensi meningkatnya kejadian kebakaran di lingkungan masyarakat dan top event atau kejadian utama yaitu terjadinya kebakaran akibat kurangnya pengawasan manajemen kebakaran karena faktor utama terjadinya kebakaran dilingkungan masyarakat adalah kurangnya pengawasan dalam mengurangi dan mengelola risiko terjadinya kebakaran yang dapat mengancam keselamatan jiwa. Manajemen kebakaran merupakan tanggungjawab semua pihak bukan hanya petugas pemadam kebakaran. Semua pihak memiliki peran dan wajib terlibat langsung dalam manajemen kebakaran mulai dari keterlibatan masyarakat dalam lingkup RT, RW serta instansi terkait untuk mencegah dan menanggulangi ancaman bahaya kebakaran. 
Berdasarkan kejadian utama dapat ditentukan empat threat atau penyebab dari keterbatasan pengawasan manajemen kebakaran. Threat yang pertama yaitu respon time atau waktu tanggap petugas lebih dari 15 menit dengan barrier untuk preventive control yaitu meningkatkan kesiapsiagaan serta keterampilan petugas pemadam kebakaran, menggunakan aplikasi sistem pelaporan kejadian kebakaran yang efektif, cepat, dan tepat kemudian meningkatkan kesadaran masyarakat untuk memberikan akses jalan kendaraan operasional pemadam kebakaran. Dengan escalation factor menurunnya kondisi fisik petugas karena kelelahan, ketidaktahuan masyarakat terkait aplikasi sistem pelaporan kebakaran dan masyarakat masih belum mau memberikan akses jalan untuk petugas.

Untuk mengatasinya dengan melakukan escalation factor control kesiapsiagaan petugas dilakukan secara bergantian serta diberikan vitamin dan latihan fisik secara rutin untuk menjaga fisik tetap prima, menyebarkan informasi melalui sosialisasi kepada seluruh masyarakat terkait aplikasi sistem pelaporan kebakaran dan melakukan pendekatan kepada masyarakat secara langsung dan tidak langsung melalui media sosial untuk menghimbau kepada masyarakat agar mengutamakan atau memberikan akses jalan kendaraan petugas.

Threat kedua kurangnya area jangkauan pelayanan pos pemadam kebakaran dengan barrier untuk preventive control yaitu meningkatkan jumlah pos pemadam kebakaran pada area yang tidak terjangkau, menyediakan APAR dan menyediakan hidran kebakaran. Dengan escalation factor sulitnya mendapatan lokasi yang cocok dan strategis serta anggaran yang terbatas untuk pembangunan pos, APAR yang telah diberikan kepada warga kurang terawat, rusak bahkan hilang serta tidak adanya regulasi yang kuat terkait serah terima dan perawatan APAR untuk masyarakat serta sulitnya penentuan lokasi, pemeliharaan hidran kebakaran dan keterbatasan anggaran.

Untuk mengatasinya dengan melakukan escalation factor control melakukan koordinasi dengan berbagai pihak dalam penentuan lokasi dan pembangunan pos serta merencanakan anggaran secara bertahap, membuat regulasi atau peraturan yang kuat terkait penyerahan APAR kepada masyarakat sehingga dapat dipertanggungjawabkan apabila hilang dan pemeliharaannya selalu terjaga serta merencanakan alokasi anggaran untuk penyediaan hidran kebakaran serta berkoordinasi dengan masyarakat dalam pembentukan sistem manajemen kebakaran di lingkungan warga terkait penggunaan dan perawatan hidran kebakaran.

Threat ketiga meningkatnya obyek yang berpotensi atau rawan terjadi kebakaran dengan barrier untuk preventive control yaitu menggunakan bahan material bangunan yang sesuai standar dan memiliki ketahanan kebakaran, membuat jarak antara bangunan dengan tata letak yang baik serta menyediakan akses jalan kendaraan operasional petugas. Dengan escalation factor sulitnya mendapatkan material bangunan yang memiliki ketahanan kebakaran, keterbatasan lahan untuk membuat jarak antara bangunan, keterbatasan lokasi untuk akses jalan. Untuk mengatasinya dengan melakukan escalation factor control menggunakan material baja ringan, komposit dan bahan lainya yang kuat dan tidak mudah terbakar serta melakukan perawatan dan perbaikan pada seluruh bangunan, menentukan desain bangunan dengan mengutamakan jarak antara bangunan serta membuat regulasi yang kuat terkait alokasi jalan yang baik sebagai persyaratan pembangunan perumahan. 
Threat keempat pemahaman serta kesadaran masyarakat yang rendah terhadap pencegahan dan pengendalian kebakaran dengan barrier untuk preventive control yaitu meningkatkan sosialisasi pemadaman kebakaran dini dan pemahaman akan potensi penyebab kebakaran, meningkatkan pelatihan penggunaan APAR untuk pemadaman api awal kebakaran serta meningkatkan pelatihan simulasi dalam menghadapi kebakaran di lingkungan warga. Dengan escalation factor sulitnya koordinasi untuk mengumpulkan warga dalam pelaksanaan sosialisasi penanggulangan kebakaran, terbatasnya ketersedian APAR dan rasa takut warga untuk mengikuti pelatihan serta keterbatasan sarana dan prasarana dalam pelaksanaan simulasi kebakaran.

Untuk mengatasinya dengan melakukan escalation factor control melakukan koordinasi dengan pendekatan internal dan melakukan kegiatan sosialisasi dengan mengikuti jadwal pertemuan warga pada saat rapat, arisan atau pertemuan $\mathrm{rt}$ atau rw, menyiapkan atau menganggarkan penyediaan APAR khusus untuk sosialisasi serta melakukan pendekatan kepada warga agar tidak takut dalam mengikuti pelatihan dan menyiapkan atau menganggarkan sarana dan prasarana penunjang untuk simulasi kebakaran.

Dari kejadian utama serta threat atau faktor penyebab dapat ditentukan tiga konsekuensi atau akibat. Konsekuensi yang pertama yaitu meningkatnya waktu pemadaman atau lamanya durasi kejadian kebakaran berlangsung dengan barrier untuk recovery control meningkatkan prasarana dan sarana yang mendukung penanggulangan kebakaran di lingkungan masyarakat, menghimbau kepada masyarakat untuk menyediakan proteksi kebakaran aktif maupun pasif pada bangunan serta tidak menyimpan atau menimbun benda atau barang yang mudah terbakar. Dengan escalation factor keterbatasan anggaran dalam penyedian serta perawatan prasarana dan sarana kebakaran untuk masyarakat, kurangnya perawatan serta tidak adanya proteksi kebakaran pada bangunan karena masyarakat atau pemilik gedung kurang peduli dan tidak mengutamakan keselamatan kebakaran serta perilaku masyarakat yang abai dengan tetap menyimpan bahan mudah terbakar tanpa proteksi kebakaran.

Untuk mengatasinya dengan melakukan escalation factor control merencanakan anggaran secara bertahap untuk penyedian serta perawatan prasarana dan sarana kebakaran di lingkungan padat penduduk, melakukan pemeriksaan proteksi kebakaran serta pendekatan kepada masyarakat untuk melengkapi bangunan nya dengan proteksi kebakaran yang baik dan menghimbau masyarakat secara langsung dan tidak langsung melalui media sosial serta menegakan peraturan dengan tegas terkait penyimpanan bahan mudah terbakar.

Konsekuensi kedua meningkatnya frekuensi kejadian kebakaran dengan barrier untuk recovery control meningkatkan ketahanan kebakaran di lingkungan masyarakat dengan menyediaan peralatan pemadaman kebakaran dini, membentuk team tanggap darurat kebakaran dalam lingkup RT dan RW serta menyelenggarakan pelatihan dan simulasi kebakaran kepada warga dalam menghadapi kebakaran. Dengan escalation factor keterbatasan anggaran untuk peralatan pemadaman kebakaran dini di lingkungan warga, sulitnya merekrut warga dalam pembentukan team tanggap darurat kebakaran serta terbatasnya ketersedian APAR dan rasa takut warga untuk mengikuti pelatihan. Untuk mengatasinya dengan melakukan escalation factor control merencanakan anggaran untuk peralatan pemadaman kebakaran dini di daerah rawan kebakaran, melakukan koordinasi dengan 
RT dan tokoh masyarakat setempat dalam pembentukan team tanggap darurat kebakaran serta menyiapkan atau menganggarkan penyediaan APAR khusus untuk sosialisasi serta melakukan pendekatan kepada warga agar tidak takut dalam mengikuti pelatihan.

Konsekuensi ketiga meningkatnya frekuensi obyek kebakaran dengan barrier untuk recovery control menggunakan material yang tahan kebakaran dan desain yang aman pada bagunan, menggunakan proteksi kebakaran aktif maupun pasif pada obyek bangunan serta menyediakan prasarana dan sarana kebakaran. Dengan escalation factor sulitnya mendapatkan material bangunan yang memiliki ketahanan kebakaran, kurangnya perawatan serta tidak adanya proteksi kebakaran pada bangunan karena masyarakat atau pemilik gedung kurang peduli dan tidak mengutamakan keselamatan kebakaran serta keterbatasan anggaran dalam penyedian serta perawatan prasarana dan sarana kebakaran pada daerah rawan kebakaran. Untuk mengatasinya dengan melakukan escalation factor control menggunakan material baja ringan, komposit dan bahan lainya yang kuat dan tidak mudah terbakar juga menggunakan desain bangunan yang baik dan aman dari bahaya kebakaran, melakukan pemeriksaan proteksi kebakaran serta pendekatan kepada masyarakat untuk melengkapi bangunan nya dengan proteksi kebakaran yang baik serta merencanakan anggaran secara bertahap untuk penyedian serta perawatan prasarana dan sarana kebakaran pada daerah rawan kebakaran.

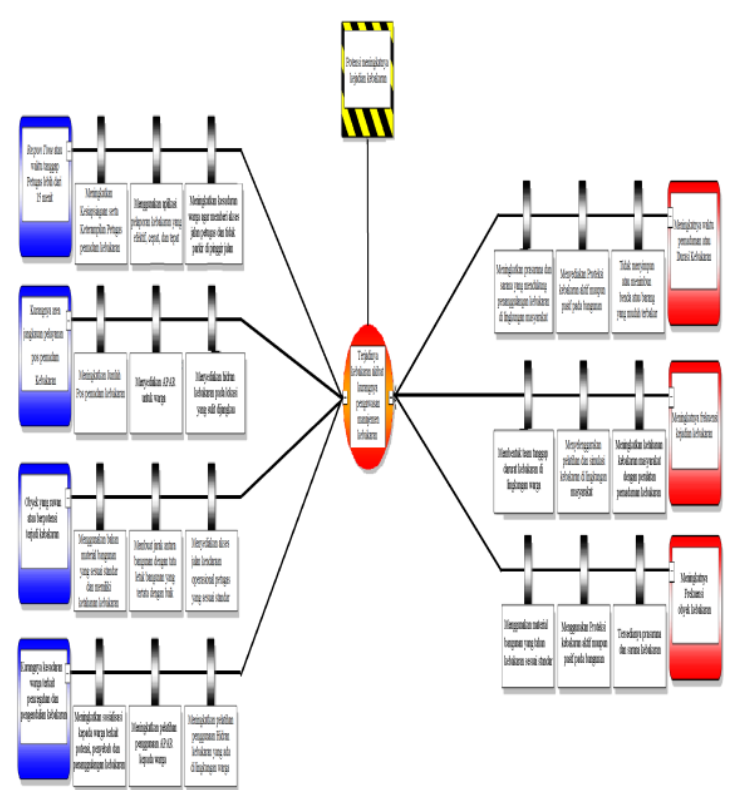

Gambar 2. Diagram bowtie analsis

\section{Analisis Strategi A'WOT Analysis Terkait Strategi Penanggulangan Kebakaran}

Untuk menentukan strategi dalam pelaksanaan tugas pencegahan dan penanggulangan kebakaran di wilayah Jakarta Timur peneliti menggunakan pendekatan analisis strategi A'WOT yaitu gabungan dari analisis SWOT dan AHP. Analytic Hierarchy Process (AHP) untuk menentukan struktur hierarki pemecahan permasalahan dalam penelitian, penghitungan evaluasi numerik dalam matriks perbandingan berpasangan menghasilkan nilai total Eigen Vektor Normalisasi perbandingan berpasangan komponen SWOT internal dan eksternal faktor. Hasil penghitungan AHP digunakan sebagai nilai bobot untuk menentukan nilai Internal Factor Analysis Summary (IFAS) dan Eksternal Factor Analysis Summary (EFAS) dalam analisis SWOT [6].

Ada beberapa tingkatan struktur hierarki tingkatan pertama tujuan yang ingin dicapai oleh organisasi yaitu keberhasilan penanganan penanggulangan kebakaran di wilayah Jakarta Timur, 
Fajar Septian: Identifikasi Hambatan pada Penanganan Penanggulangan Kebakaran di Wilayah Jakarta Timur Menggunakan Metode Bowtie Analysis dan A'WOT Analysis Jurnal Migasian, e-issn : 2615-6695 / p-issn : 2580-5258

tingkatan kedua adalah faktor kriteria yaitu indikator atau variabel penelitian diantaranya respon time atau waktu tanggap petugas terhadap peristiwa kebakaran dengan target waktu tidak lebih dari lima belas menit, potensi obyek kebakaran, kesiapsiagaan petugas dan masyarakat dalam usaha pemadaman kebakaran serta pemetaan wilayah rentan kebakaran terhadap area jangkauan pelayanan pos pemadam kebakaran. Tingkatan Ketiga merupakan faktor dalam analisis SWOT. Setelah menentukan struktur hierarki kemudian menentukan nilai Internal Factor Analysis Summary (IFAS) dan Eksternal Factor Analysis Summary (EFAS) perbandingan berpasangan antara kelompok SWOT dengan penghitungan bobot menggunakan Analytic Hierarchy Process (AHP). Nilai bobot dan Rating yang didapatkan berdasarkan pendapat para ahli yaitu petugas pemadam kebakaran yang bertugas di wilayah Jakarta Timur dari penilaian rata - rata jawaban para responder ahli dengan mengisi Kuesioner.

Tabel 2. Internal Factor Analysis Summary (IFAS)

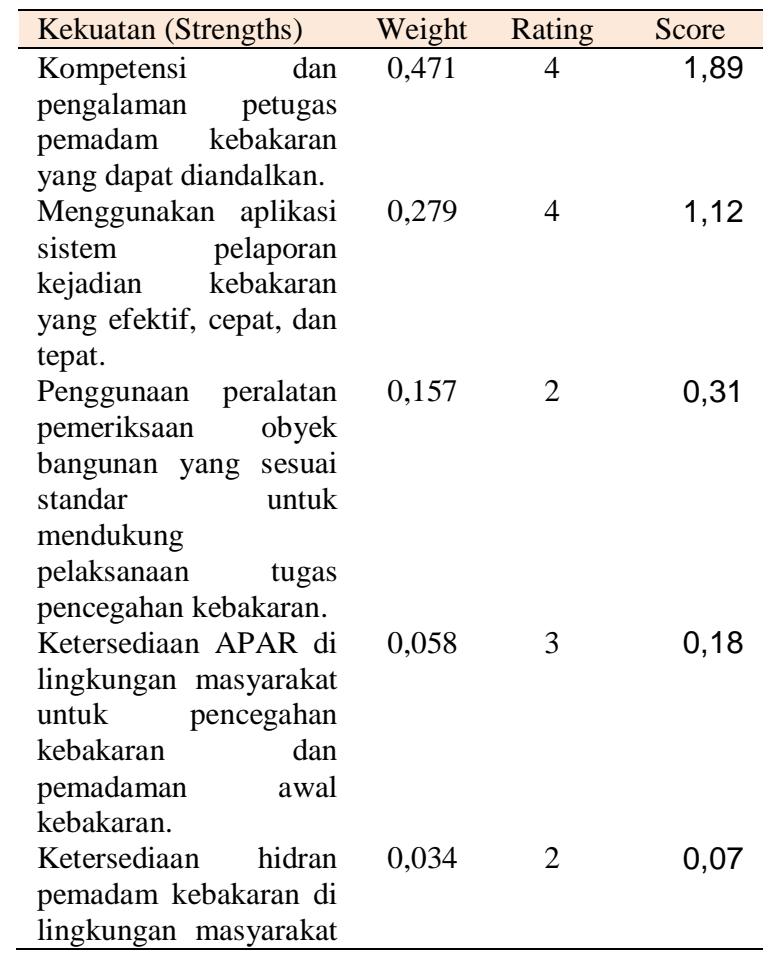

\begin{tabular}{|c|c|c|c|}
\hline $\begin{array}{l}\text { padat penduduk untuk } \\
\text { membantu dan } \\
\text { mendukung } \\
\text { pemadaman kebakaran. }\end{array}$ & & & \\
\hline Total & 1 & & 3,56 \\
\hline $\begin{array}{l}\text { Kelemahan } \\
\text { (Weaknesses) }\end{array}$ & Weight & Rating & Score \\
\hline $\begin{array}{l}\text { Terbatasnya jumlah pos } \\
\text { pemadam kebakaran di } \\
\text { wilayah jakarta timur. }\end{array}$ & 0.533 & 3 & 1.60 \\
\hline $\begin{array}{l}\text { Kurangnya } \\
\text { petugas jumlah } \\
\text { kebakaran di wilayah } \\
\text { jakarta timur. }\end{array}$ & 0,250 & 3 & 0,75 \\
\hline $\begin{array}{lr}\text { Terbatasnya } & \text { kendaraan } \\
\text { operasional } & \text { dan } \\
\text { peralatan pendukung } \\
\text { pemadaman kebakaran. }\end{array}$ & 0,123 & 3 & 0,37 \\
\hline $\begin{array}{l}\text { Respon time atau } \\
\text { waktu tanggap petugas } \\
\text { pemadam kebakaran } \\
\text { lebih dari } 15 \text { menit. }\end{array}$ & 0,068 & 2 & 0,14 \\
\hline $\begin{array}{lr}\text { Terbatasnya } & \text { jumlah } \\
\text { petugas pemeriksa } \\
\text { sistem } & \text { keamanan } \\
\text { kebakaran } & \text { pada } \\
\text { bangunan tinggi atau } \\
\text { bangunan bertingkat }\end{array}$ & 0,027 & 2 & 0,05 \\
\hline Total & 1 & & 2,91 \\
\hline
\end{tabular}

Tabel 3. External Factor Analysis Summary (EFAS)

\begin{tabular}{|c|c|c|c|}
\hline Peluang $(\mathrm{O})$ & Weight & Rating & Score \\
\hline $\begin{array}{lr}\text { Petugas } & \text { pemadam } \\
\text { kebakaran } & \text { Sudin } \\
\text { Damkar Jakarta } & \text { Timur } \\
\text { melaksanakan sosialisasi } \\
\text { pemadaman } & \text { kebakaran } \\
\text { dini dan pemahaman } \\
\text { akan potensi } & \text { penyebab } \\
\text { kebakaran } & \text { kepada } \\
\text { warga. } & \end{array}$ & 0,448 & 4 & 1,79 \\
\hline $\begin{array}{lr}\text { Petugas } & \text { pemadam } \\
\text { kebakaran } & \text { Sudin } \\
\text { Damkar Jakarta Timur } \\
\text { melaksanakan pelatihan } \\
\text { penggunaan APAR } \\
\text { untuk pemadaman api } \\
\text { awal kebakaran kepada } \\
\text { warga. }\end{array}$ & 0,297 & 3 & 0,89 \\
\hline $\begin{array}{lr}\text { Petugas } & \text { pemadam } \\
\text { kebakaran } & \text { Sudin } \\
\text { Damkar Jakarta } & \text { Timur } \\
\text { melakukan } & \text { peningkatan } \\
\text { kesadaran } & \text { masyarakat } \\
\text { untuk memberikan akses } \\
\text { jalan } & \text { kendaraan } \\
\text { operasional } & \text { pemadam } \\
\text { kebakaran } & \text { melalui } \\
\text { pendekatan } & \text { dan } \\
\text { sosialisasi } & \text { kepada } \\
\text { masyarakat. } & \end{array}$ & 0,153 & 3 & 0,46 \\
\hline
\end{tabular}




\begin{tabular}{|c|c|c|c|}
\hline $\begin{array}{l}\text { Penggunaan bahan } \\
\text { material bangunan yang } \\
\text { sesuai standar, memiliki } \\
\text { ketahanan kebakaran } \\
\text { dan desain bagunan yang } \\
\text { aman dari risiko } \\
\text { kebakaran. } \\
\text { Peraturan perundang - } \\
\text { undangan r yang } \\
\text { mendukung pelaksanaan } \\
\text { tugas a pemadam } \\
\text { kebakaran. }\end{array}$ & 0,075 & 2 & 0,15 \\
\hline Total & 1 & & 3,37 \\
\hline Ancaman (T) & Weight & Rating & Score \\
\hline $\begin{array}{lr}\text { Kurangnya } & \text { pemahaman } \\
\text { serta } & \text { kesadaran } \\
\text { masyarakat } & \text { terhadap } \\
\text { pencegahan } & \text { dan } \\
\text { pengendalian } & \text { kebakaran. }\end{array}$ & 0,440 & 3 & 1,32 \\
\hline $\begin{array}{l}\text { Akses jalan yang sempit } \\
\text { dan terbatas untuk } \\
\text { kendaraan operasional } \\
\text { petugas. }\end{array}$ & 0,303 & 2 & 0,61 \\
\hline $\begin{array}{l}\text { Kurangnya area } \\
\text { jangkauan pelayanan pos } \\
\text { pemadam kebakaran di } \\
\text { wilayah jakarta timur. }\end{array}$ & 0,137 & 3 & 0,41 \\
\hline $\begin{array}{lr}\text { Meningkatnya } & \text { obyek } \\
\text { bangunan } & \text { yang } \\
\text { berpotensi atau rawan } \\
\text { terjadi kebakaran. }\end{array}$ & 0,088 & 2 & 0,18 \\
\hline $\begin{array}{l}\text { Meningkatnya waktu } \\
\text { pemadaman atau } \\
\text { lamanya durasi kejadian } \\
\text { kebakaran berlangsung. }\end{array}$ & 0,032 & 3 & 0,10 \\
\hline Total & 1 & & 2,61 \\
\hline
\end{tabular}

Kemudian dengan analisis SWOT dapat ditentukan nilai Matrix Internal dan Eksternal Strategy dari nilai IFAS dan EFAS yang telah didapatkan menggunakan matriks strategi Eksternal Factor Evaluation (EFE) dan Internal Factor Evaluation (IFE) yang bertujuan untuk menentukan arah strategi dalam pengembangan organisasi di masa depan. Letak posisi matriks strategi ditentukan dengan menggabungkan hasil nilai total skor matriks IFAS serta nilai total skor matriks EFAS. Melalui merger dengan posisi pada saat sekarang berdasarkan strategi keberhasilan penanggulangan kebakaran dan penyelamatan di wilayah Jakarta Timur dapat diketahui serta dapat ditentukan strategi yang paling relevan yang akan digunakan kedepannya [7].
Nilai Eksternal Faktor Evaluation (EFE) sebesar 2,99 termasuk kategori menengah artinya faktor eksternal organisasi berada pada keadaan stabil dan kuat. Nilai skor faktor peluang sebesar 1,69 sedangkan nilai skor faktor ancaman sebesar 1,30 memiliki selisih nilai sebesar 0,39 . Menunjukan faktor eksternal dalam aspek peluang mempunyai nilai yang lebih berpengaruh dari faktor ancaman pada saat sekarang.

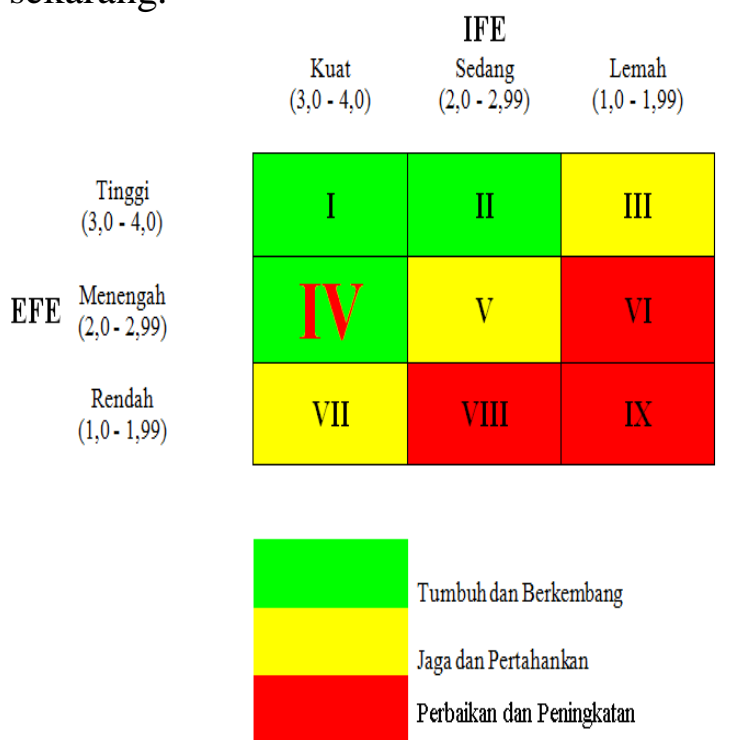

Gambar 3. Matriks Strategi Eksternal Factor Evaluation dan Internal Factor Evaluation

Serta nilai Internal Factor Evaluation (IFE) sebesar 3,23. Untuk nilai faktor kekuatan sebesar 1,78 dan skor nilai faktor kelemahan sebesar 1,45 terdapat selisih sebesar 0,33. Hal ini menunjukan bahwa faktor kekuatan lebih dominan dibandingkan dengan faktor kelemahan organisasi. Nilai total Eksternal Factor Analysis Summary (EFAS) pada matriks nilai Eksternal Factor Evaluation (EFE) sebesar 2,99 yang nilainya lebih rendah dari pada nilai total Internal Factor Analysis Summary (IFAS) untuk matriks nilai Internal Factor Evaluation (IFE) sebesar 3,23. Hal ini dapat diartikan bahwa faktor internal organisasi suku dinas penanggulangan kebakaran dan 
penyelamatan di wilayah Jakarta Timur lebih banyak mengendalikan dan menentukan strategi organisasi dibandingkan pilihan faktor eksternal. Hasil perhitungan matriks strategi Internal dan Eksternal diperoleh strategi organisasi yang dapat diterapkan yaitu strategi integrasi antara EFE dan IFE pada kuadran IV yaitu kondisi yang tumbuh dan berkembang, organisasi suku dinas penanggulangan kebakaran dan penyelamatan di wilayah Jakarta Timur mendapatkan kekuatan organisasi serta peluang organisasi agar secara berkelanjutan berkembang dan meningkat terus tumbuh serta terintegrasi dengan lingkungan.

\section{KESIMPULAN}

Trend kejadian kebakaran pada wilayah kecamatan di Jakarta Timur untuk tahun 2020 yang terbanyak terjadi di kecamatan duren sawit $17 \%$, cakung $16 \%$, dan pulo gadung $14 \%$. Respon time petugas terhadap peristiwa kebakaran yang sesuai target waktu 15 menit sebesar 98\% sedangkan $2 \%$ tidak mencapai target waktu. Hambatan dalam mencapai respon time 15 menit diantaranya kondisi lalulintas yang padat, akses jalan sempit serta pengguna jalan yang tidak memberikan atau mengutamakan akses jalan kepada petugas untuk menuju ke lokasi kebakaran.

Obyek kebakaran terbanyak terjadi pada bangunan perumahan $28 \%$ dan instalasi luar gedung $26 \%$. Hambatannya yaitu meningkatnya jumlah obyek yang berpotensi atau rentan terjadi kebakaran khususnya pada bangunan perumahan karena kurangnya kepedulian masyarakat terhadap potensi penyebab kebakaran serta tidak tersedianya proteksi kebakaran dan sarana penanggulangan kebakaran. Kesiapsiagaan Petugas dan Masyarakat dalam usaha pemadaman kebakaran, yang dapat diantisipasi oleh masyarakat 19\%, sedangkan yang dipadamkan petugas $81 \%$.
Hambatannya yaitu pemahaman serta kesadaran masyarakat yang rendah terhadap pencegahan dan pengendalian kebakaran menjadikan masyarakat tidak peduli dengan lingkungannya sehingga rawan terjadi kebakaran. Dari total luas wilayah Jakarta Timur 188,03 $\mathrm{Km}^{2}$ luas area jangkauan pelayanan pos pemadam kebakaran yang menjangkau masyarakat sebesar 160,59 $\mathrm{Km}^{2}$ atau $85 \%$ sedangkan luas area yang tidak terjangkau dengan radius jangkauan pelayanan pos pemadam kebakaran sebesar $27,44 \mathrm{Km}^{2}$ atau $15 \%$. Hambatan terkait kurangnya area jangkauan pelayanan pos pemadam kebakaran yaitu sulitnya mendapatkan lahan yang tepat untuk pembangunan pos pemadam kebakaran serta area jangkauan pelayanan pos pemadam kebakaran tidak merata.

Strategi prioritas utama yaitu peningkatan jumlah pos pemadam kebakaran nilai bobot 0,533 . Prioritas kedua peningkatan kompetensi dan pengalaman petugas yang dapat diandalkan nilai bobot 0,471 . Prioritas ketiga peningkatan sosialisasi pencegahan dan pemadaman kebakaran dini kepada warga dengan nilai bobot 0,448 .

Implikasi manajerial yang dapat dilakukan dengan mendirikan pos pemadam kebakaran di sekitar wilayah yang belum menjangkau masyarakat untuk memberikan pelayanan terbaik kepada warga terkait ketepatan waktu respon time petugas, mempermudah dalam melaksanakan sosialisasi pencegahan dan penanggulangan kebakaran serta pelayanan bencana lainnya. Serta melaksanakan peningkatkan sosialisasi, himbauan, pelatihan, simulasi kebakaran kepada masyarakat secara berkala dan menyeluruh agar masyarakat lebih peduli terhadap ancaman bahaya kebakaran.

\section{UCAPAN TERIMAKASIH}


Penulis mengucapkan terimakasih kepada Sudin Penanggulangan Kebakaran dan Penyelamatan Jakarta Timur atas izin melakukan penelitian dan kesediaannya memberikan informasi dan arahannya kepada penulis dalam menyusun penelitian ini.

\section{DAFTAR PUSTAKA}

[1] S. Tridala, "Model Penentuan Lokasi Potensial Prasarana Mitigasi Bencana Kebakaran Perkotaan Sebagai Salah Satu Dasar Penataan Ruang Wilayah Kota Pantai Kendari”, Dr. disertasi, Sekolah Pasca Sarjana Universitas Hasanuddin, Makasar, 2017.

[2] DPKP DKI Jakarta, Rencana Strategis 2017 - 2022. Jakarta : Dinas Penanggulangan Kebakaran dan Penyelamatan DKI Jakarta, 2018.

[3] J. Ahmad, "Desain Penelitian Analisis Isi (Content Analysis)", Researchgate, 01-20, June, 2018.

[4] S. Ramli, Manajemen Risiko dalam Prespektif K3 OHS Risk Management Berbasis ISO 31.000, Bekasi, Yayasan
Pengembangan Keselamatan Prosafe Institute, 2018.

[5] M. D. D. Maharani, Sumardjo, Eriyatno, E. S. Pribadi, "Strategi Pengolahan Usaha Jasa Rumah Pemotongan Hewan Ruminansia Secara Berkelanjutan", Jurnal Veteriner, vol. 18, no. 1, pp. 94 - 106 Maret, 2017.

[6] Ramazan G, Akyay U, "Awot Method In Identification And Development Of Tourism Potential Of Destination Area: Beyşehir Application", Asian Academic Research Journal of Social Sciences \& Humanities. vol. 2, no. 12, pp. 126 142. November, 2015.

[7] Saudin, Bambang A. N, Mudzakir A. K, "AWOT Analysis In Small-Scale Fishing Management In Marine Waters Of Indramayu Regency. RJOAS: Russian Journal Of Agricultural and Socio-economic Sciences. vol. 6, no.90, pp. 168 - 177. June, 2019. 